解説

Explanation

\section{JRCS Digital Innovation LAB の取り組み*}

\section{1.はじめに}

JRCS（以下，弊社）は 2018 年 4 月に Digital Innovation LAB(以下，DIL)を設立した。

DILとはデジタルトランスフォーメーションを推進 し，カルチャーチェンジを行うための組織であり，現 在リリースしている infinity training や infinity assist, 今後リリース予定である infinity command な どのデジタル製品の開発やサービス提供をしている.

DIL は海上物流の円滑化を通じ，海運・海洋産業に携 わる人，その先にいるすべての人を笑顔にすることを ミッションに掲げ活動をしている.

創業以来, 舶用メーカーとして海運・海洋産業に携 わってきた弊社がなぜデジタルトランスフォーメーシ ヨンを推進するための組織を設立し，デジタル製品の 開発や提供，カルチャーチェンジを進めているのか, 製品の概要などは第 54 巻第 5 号で紹介しているので 簡単に留め, 本稿では, DIL が発足してから今日まで に取り組んでいるデジタルトランスフォーメーション やカルチャーチェンジ，その取り組みを紹介する.

\section{2. デジタルソリューション}

弊社はデジタルプラットフォーマーとして，海運・ 海洋マーケットのパートナーと新たな価值を共創する ために, Mixed Reality (複合現実, 以下 MR) と AI(人 工知能) を活用した「infinity training $」 「$ infinity assist」・「infinity command」の3つのロードマップ を作成し開発に取り組んでいる.

まず, 2019 年 4 月に $\mathrm{MR}$ や $\mathrm{AI}$ を活用した効果的な 人材育成の仕組みである, 人をサポートするためのソ リューション「infinity training」の提供を開始した.

*原稿受付 令和 2 年 4 月 9 日.

$* * J R C S$ 株式会社(山口県下関市東大和町 1 丁目 2 番 14 号)

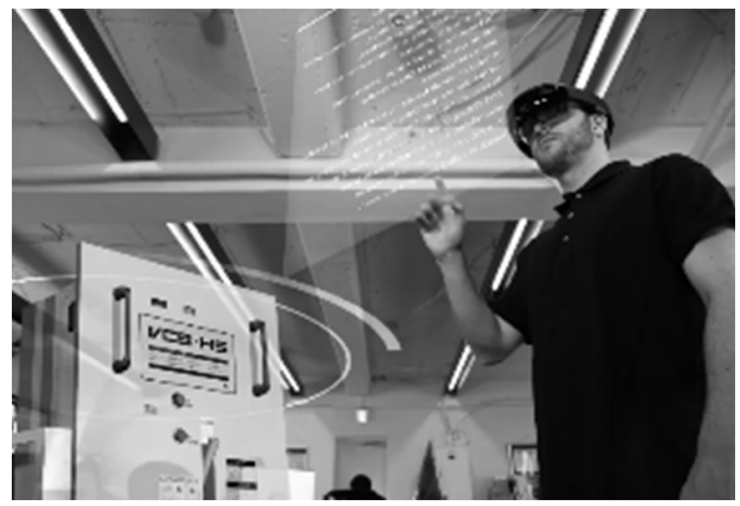

図 1 infinity training イメージ

次に，船員やメーカー技師の負担や人的ミスを軽減 する遠隔メンテナンスソリューションである「infinity assist」の開発を進めている. 2020 年 5 月には MVP

(Minimum Viable Product) となるタブレットを利 用し, 突発的な船舶搭載機器のトラブルを解決するた めのサービスの提供を開始した. 今後は MR などの工 ッジデバイスを活用し，レギュラーメンテナンス・リ モートアシストなどの機能を拡充していき船員の働き 方改革を推進する.

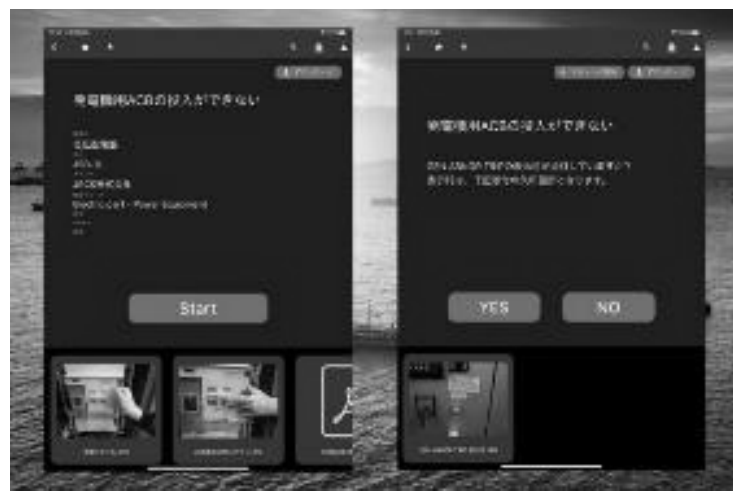

図 2 infinity assist イメージ

infinity assist と並行して開発を進めているプロジ エクトが「infinity command」である.これは自動運 
航船を見据えた運航支援システムであり，IoT，AI な どの技術とビッグデータを活用することで，船舶操船 を担うキャプテンが近い将来, デジタルキャプテンと して陸上から複数の船舶をコントロールする操船ソリ ユーションとなる. infinity command はコンピュータ 一ビジョン技術を用いて開発を行っている. MVP と して 2020 年夏には操船者がタブレットを利用し, 光 学カメラから取得した映像を基に海上の状況認識を行 い，船舶の安全運航を支援するサービスをリリース予 定であり, 船舶の安全だけでなく操船者の負担を軽減 することで労働環境を改善していく.

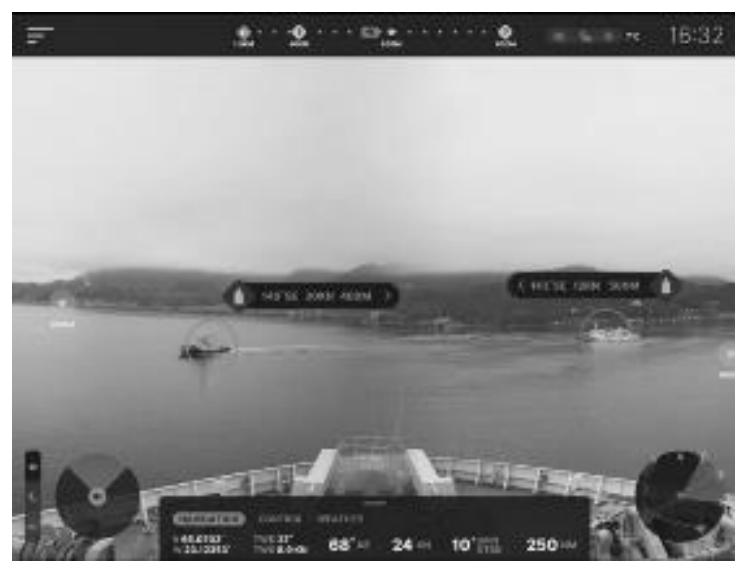

図 3 infinity command イメージ

\section{3. デジタルトランスフォーメーション}

デジタルトランスフォーメーションを推進し, 浸透 させるためには, 社内への理解やカルチャーチェンジ が必要不可欠である. そのため, これまでに DIL が社 内や社員に対して実施していることや, 働き方改革の 一環として実施している取り組みを紹介寸る.

\section{1 デザイン思考}

DIはソリューションを生み出すための手法として， デジタルサービスを検討，展開寸る際にデザイン思考 を取り入れている. そして，「もの」による解決ではな く, ユーザーの本質的なニーズを見つけ出しイノベー ションを起こすための問題解決のプロセスを大事にし ている.これはユーザーの要望を聞き問題解決をする ことではなく, ユーザーの言動からユーザーの欲しい ものをより深く分析し, 要望を定義することである. ユーザーよりもユーザーのことを深く理解することで, ユーザーが気づいていない問題を見つけ出し, 解決す る. この際, ユーザーの行動や感情, 思考, 課題など を把握するためにカスタマージャーニーマップやユー ザーストーリーを作成している.
デザイン思考には共感（Empathize），問題定義 (Define), 発想・概念化 (Ideate), 試作 (Prototype), 試験（Test）の 5 つのステップがある. ステップ1で はユーザーが何を求め, 何を考えているのかといった ニーズを探しだし，実際にサービスを利用したユーザ 一がどのように感じ，何を思うのかを把握することを 目的として作業を実施する，ステップ 2 では，ユーザ 一が抱く疑問や問題点を調べ，その内容をべースにユ ーザーの真のニーズを洗い出す．そして問題がどこに あるのかを明確に定義する，ステップ 3 ではステップ 2 で定義された問題点に対して, 具体的にどのように アプローチをするべきか考える. この時, 社員やメン バーを集め，枠にとらわれることなく自由に意見交換 を行い，より多くのアイデアを出しあい方策を練る.

このステップでは仮説を具体化することがポイントと なる. ステップ 4 では，ステップ 3 の発想・概念化で 出た方策や方向性が固まったら試作を行う。試作品を 作成することでアイデアの再現が容易になり，具体的 でより良いイメージのもとサービス性能や効果，実現 性について検討することができる，試作品を作成する ことで，解決策の提案では説得力を補強することがで きる．最後にステップ 5 では社内での検討を経て，い よいよユーザーにアイデアの使用感を問う。それまで に行った方針が正しかったのか否かを見極めるだけで なく, 今後の課題を決める重要な段階となる. テスト と改善を繰り返し, 最終的な解決策（ゴール）を目指 す.デザイン思考は実践的で創造的な問題解決の手法 であり，得られる結果をよりよくすることができると 考える.

デザイン思考はデジタルサービスのみでなく，全て の製品開発において最も重要なプロセスの一つだと言 える.

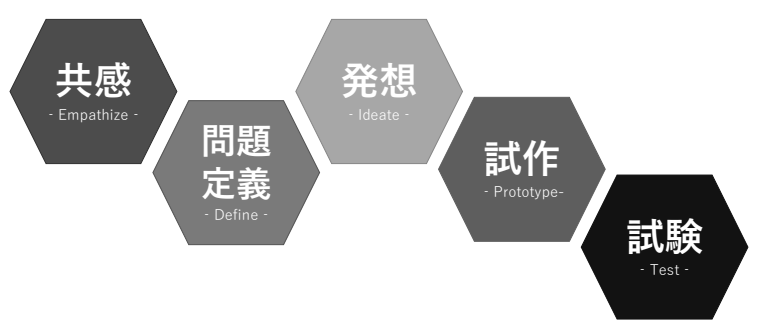

図 4 デザイン思考 - 5 ステップ -

デザイン思考を取り入れる中で，カスタマージャー ニーマップやユーザーストーリーを作成していると先 に述べたが，なぜそれらを作成するのか．それはユー ザーの行動や感情, 思考, 課題などを把握でき, チー 
ムで共通認識を持つことができる．また，解決すべき 課題や問題点の優先事項は何かを明確にできるからだ. これらを作成することで，ユーザーが課題と感じてい ることに対してその裏ではどのような行動をとってい るのか, どう感じているのか, 問題点や課題は何なの かを明確にし, 課題解決に向けてカスタマージャーニ ーマップやユーザーマップを作成している.

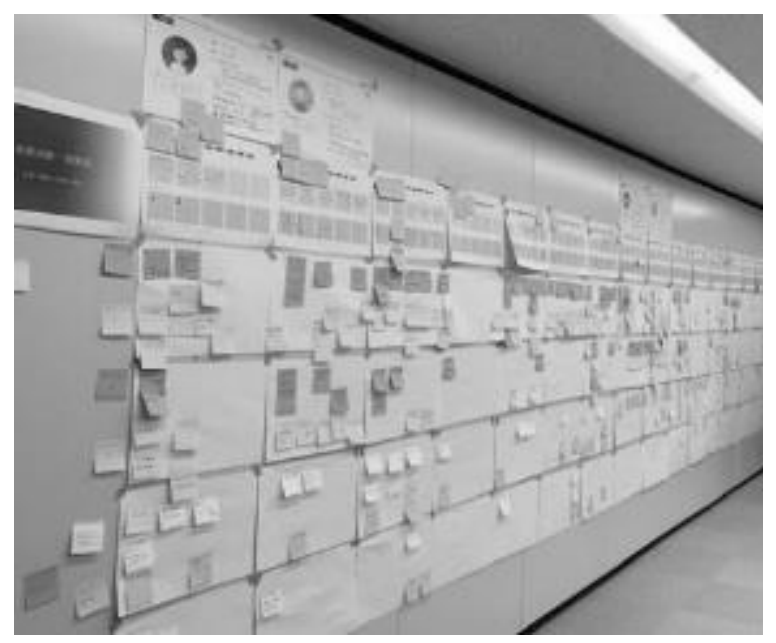

図 4 社内ワークショップで作成した カスタマージャーニーマップ

\section{2 インナーコミュニケーション}

弊社が舶用専業メーカーからデジタルカンパニーへ と変革するために社内で大切にしていることは社員へ のインナーコミュニケーションである.

創業以来，船舶盤メーカーとして製品の設計から製 造，サービスを行ってきた，そのため，デジタルトラ ンスフォーメーションとは何なのか, デジタル化をす ることでどのようなことが起きるのか, など社員に対 しての説明を行い，疑問や不安を取り除くことはDIL の重要な役割だと考える. その手段として, 社員参加 型のインナーコミュニケーションを取り入れ, 社員の カルチャーチェンジをサポートするとともに，デジタ ルトランスフォーメーションに対する社員への理解を 深めている. 4 つのインナーコミュニケーションを定 期的に実施することでデジタルトランスフォーメーシ ヨンに対する，社員の考え方が徐々に変化してきてお り，弊社のカルチャーチェンジが進んでいることを実 感している.

\section{2.1 対話}

社員全員にデジタルトランスフォーメーションやカ ルチャーチェンジを浸透させるために重要なことは, CEO (Chief Executive Officer) や CDO (Chief Digital
Officer）が直接説明会や懇談会を実施し，自らの想い や考え，志を直接伝えることである．この対話を定期 的に開催することで，社員の不安や疑問を取り除くこ とにつながっている. また，DIL として定期的にデジ タルトランスフォーメーションに対する DIL の取り 組みやデジタル製品の紹介等についての説明会や勉強 会を開催することで，トランスフォーメーションに対 する社員の理解が深まっている.

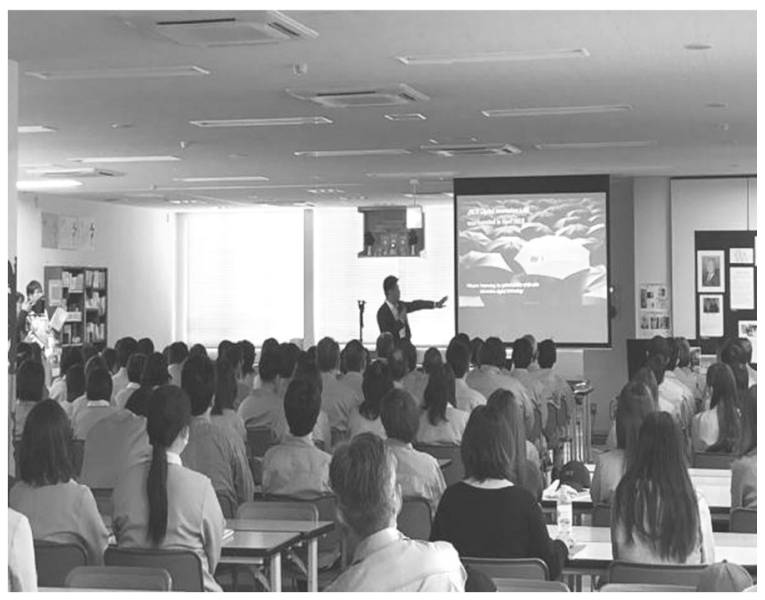

図 5 社内説明会

\section{2.2 デジタルツール}

弊社には社員専用の社員サイト「BRIDGE」がある. その中でデジタル通信と題して，些細なことから，ワ ークショップ, デジタル関連の参考書籍, DIL の日々 の活動などを投稿している.ここでは一方的な伝達ツ ールではなく，記事や DIL に対する質門に関して， SNS と同様に投稿した内容に対して「いいね！」をつ ける機能やコメントができる環境があり，双方向から のコミュニケーションが取れる場所となっている.
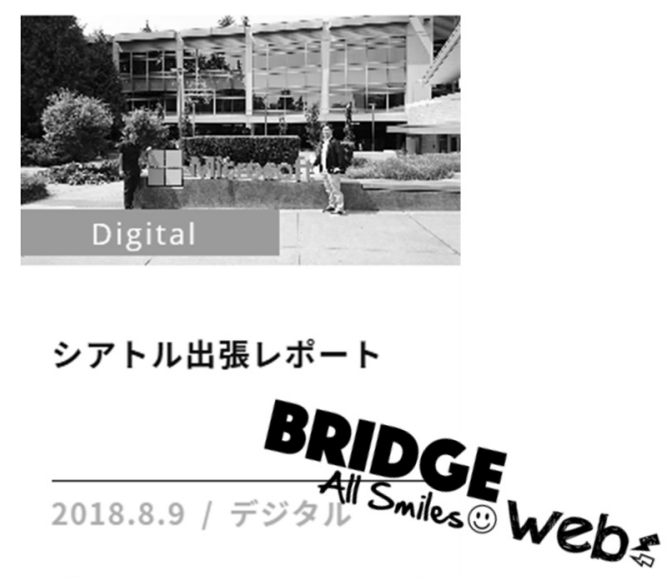

「いいね!」(10)コメント(0)

図 6 社員サイト 
紙媒体のアナログツールを活用し，会社としてデジ タルカンパニーを目指寸想いや方向性などの重要な情 報を社内会報に投函し伝えている。 これは社員へ正確 な情報を伝えるとともに，アンケートを実施し社員の 考えや想い，疑問などをフィードバックしている.

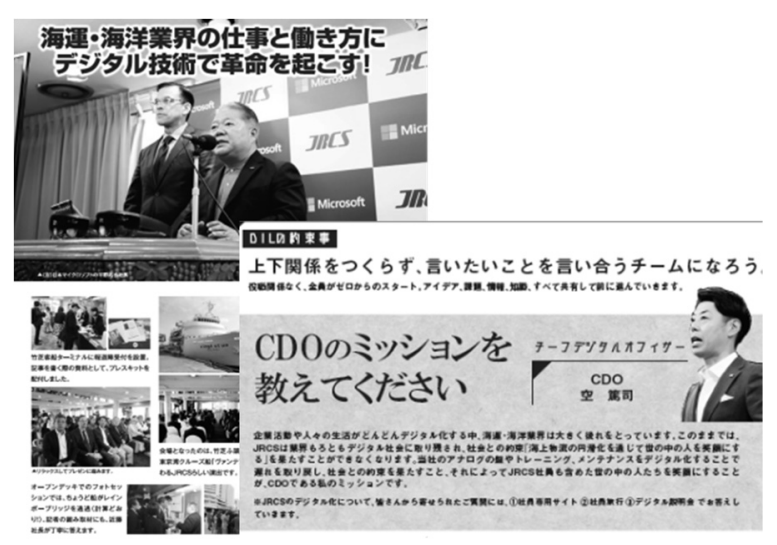

図 7 社内会報

\section{2.4 デジタル体験}

我々の生活の中にはすでに多くのデジタルが潜んで いる，例えばスマートフォン 1 台あればいつでも，ど こでもデジタル体験ができるようになった．意識しな いとデジタル体験をしているということに気づかない が，普段の生活の中で自身の体験とデジタルを結びつ けることでデジタル化に対する理解を深めている.

また, 説明会や勉強会を通して実際に MR や Augmented Reality（拡張現実, AR), Virtual Reality（仮想現実, VR）などの体験や身近に潜んで いるデジタルを体験してもらい, デジタルトランスフ オーメーションを自分事化している.

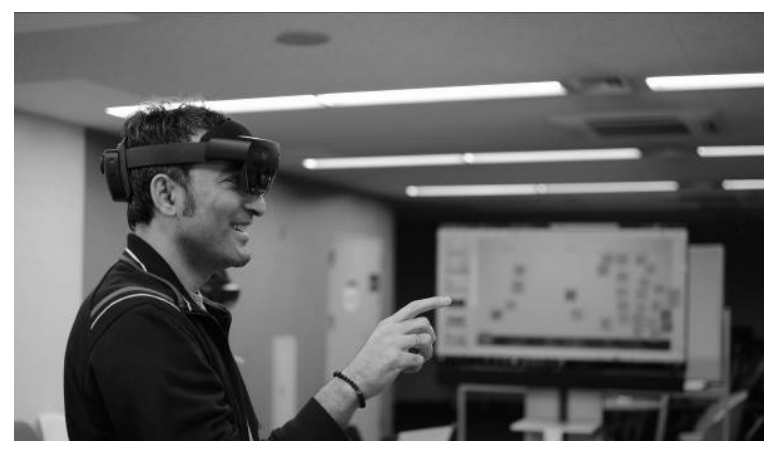

図 8 デジタル体験

3.3 シアトル, シリコンバレ一訪問
私は 2018 年 11 月に IT 企業の先端技術をビジネス に応用すること，デジタル技術を組織，システムに順 応させるためのヒューマンアプローチを学ぶことを目 的としてシアトルとシリコンバレーを訪問した．滞在 中，様々なセッションを受けたが，特に印象に残った ことは，セッションを受けた全ての企業から「カルチ ヤーチェンジ」や「変わる努力をしている」という言 葉を聞いたことだ，失敗を恐れるリスクばかりを先行 させるとイノベーションは生まれない. 失敗する事を 挑戦と捉えるプロトタイプ文化を根付かせることがイ ノベーションの第一歩であるということを理解した. 例えば，問題解決のプロセスであり，人間中心の考え 方，イノベーションのためのマニュアルである「デザ イン思考」を企業文化に根付かせることで，古くて変 わりにくい企業から世界で最もイノベーティブな企業 の一つへと変革を遂げた企業がある. この企業のよう に，私たちも古い固定概念や考え方に囚われず，新た な挑戦をするという強い意志を持って変革を続けてい $<$.

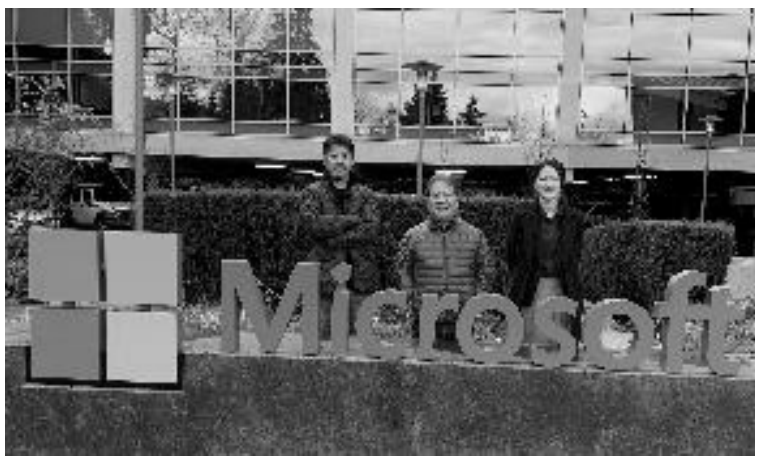

図 9 シアトル，シリコンバレー訪問

\section{4 Digital Innovation LAB オープン}

社員の働き方改革の一環として, 2019 年 3 月, 下 関本社に脱オフィスをコンセプトにしたスペース

「Digital Innovation LAB」をオープンした. オフィ スといら概念に囚われず, 落ち着いた雾囲気の中でリ ラックスして業務ができる環境, そして, 自由な発想 や活発なアイデアを生むためのワークショップスペー スとして活用できるようにリノベーションを実施した。 さらに，フリーアドレスとしたことでデスクトップや 電話機を設置せず，ペーパーレスを考えコピー機など のオフィス機器を一切設置していない. このスペース は普段の業務だけでなく，オープンスペースとしてお 客様とのワークショップでも活用しており, カフェの ような空間の中で活発な意見交換を可能にしている.

Digital Innovation LAB をオープンするにあたり， 設計段階では普通のオフィスで良いのではないかとい 
う否定的な意見も出ていた. しかし，普通のオフィス というバイアス(固定概念) は取り外し，新たな挑戦と して Digital Innovation LAB をオープンした. 現在で は, 豊浦事業所内や東京本社でもリノベーションが行 わ机働きやすい環境つくりを社員自らが実施している.

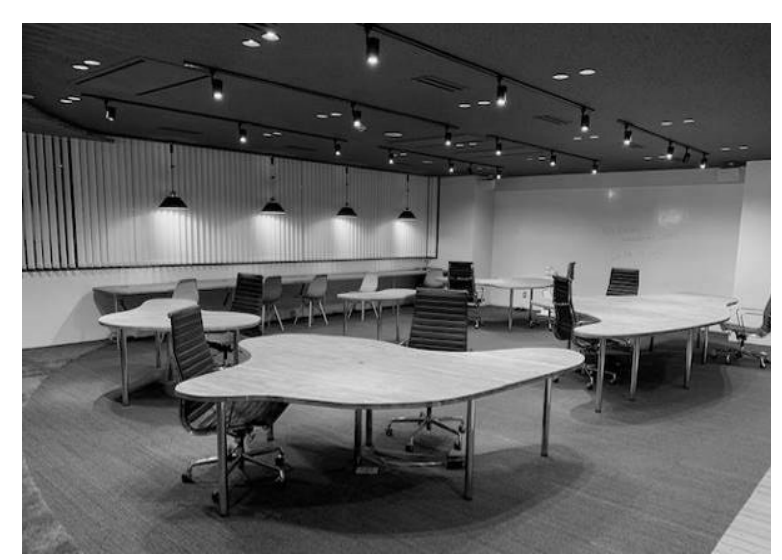

図 10 Digital Innovation LAB 室内

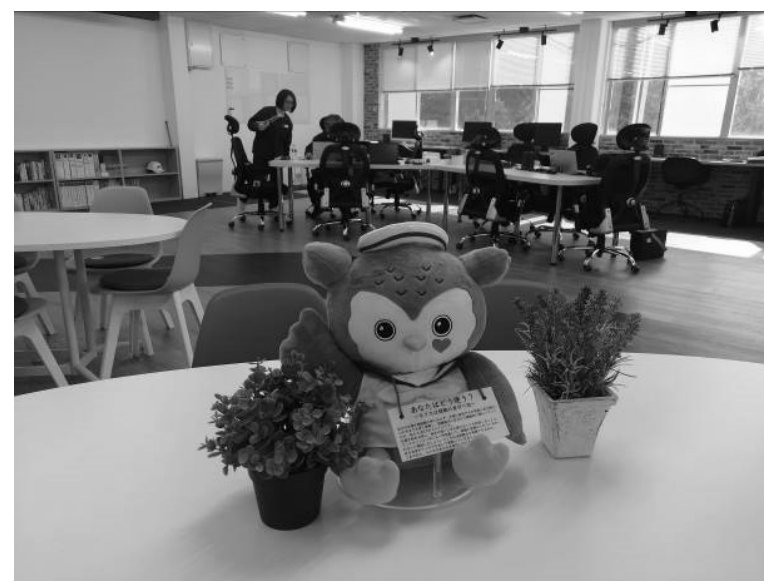

図 11 豊浦事業所内

\section{4. 最後に}

本稿では, DIL の取り組みについて紹介してきた. DIL のミッションである,「海洋に携わる人，その先 にいるすべての人を笑顔にすること.」を達成するため にも,海運・海洋産業の課題やニーズを的確に把握し, 新たなソリューションを提供していく必要がある. 最 新のデジタル技術を駆使し，市場に新たな価值を提供 することで, 海運・海洋産業の働き方改革を進めてい $<$.

また，デジタルトランスフォーメーションを浸透さ せるために, 社内の説明会や勉強会, デジタル体験も 引き続き開催し, 社員への理解を深めていく.

私たちは舶用専業メーカーからデジタル企業へ転換
するために，市場に新たなソリューションや価值を提 供し, さらに, 社内のトランスフォーメーションを推 進するための挑戦をこれからも続けていく.

\section{著者紹介}

岡部 藍花

- 1992 年生

- 所属 JRCS 株式会社

・最終学歴 九州職業能力開発大学校 生産電子システム技術科 修了 